\title{
HUBUNGAN KOMPONEN RUMAH SEHAT TERHADAP KEJADIAN \\ PNEUMONIA PADA BALITA DI WILAYAH KERJA PUSKESMAS SIMPANG AGUNG KABUPATEN LAMPUNG TENGAH TAHUN 2018
}

\author{
Dina Audia Pratiwi ${ }^{1)}$
}

\begin{abstract}
Abstrak
Pneumonia adalah infeksi akut pada paru-paru, yang mengakibatkan paru-paru terisi cairan sehingga terjadi gangguan pernafasan akibat penurunan kemampuan paru-paru dalam menyerap oksigen. Salah satu faktor risiko ekstrinsik pneumonia adalah kondisi rumah. Rumah yang tidak memenuhi syarat kesehatan terkait erat dengan penyakit berbasis lingkungan salah satunya penyakit pneumonia. Tujuan dari penelitian untuk mengetahui hubungan komponen rumah sehat terhadap kejadian penyakit pneumonia pada balita di Wilayah Kerja Puskesmas Simpang Agung Kabupaten Lampung Tengah.

Penelitian ini adalah studi analitik yaitu penelitian untuk menggali bagaimana dan mengapa suatu fenomena kesehatan terjadi dan melakukan analisis dinamika korelasi antara faktor risiko dan faktor efek dengan rancangan penelitian kasus kontrol (case control).

Hasil penelitian menunjukkan bahwa terdapat variabel yang memiliki hubungan dengan kejadian pneumonia. Komponen rumah yang berhubungan dengan kejadian pneumonia adalah ventilasi ( $p$ value: $0,033, \mathrm{OR}=4,041)$, langit-langit ( $p$ value: $0,017, \mathrm{OR}=6,769)$ dan lantai $(p$ value: $0,038, \mathrm{OR}=$ $2,627)$ dan komponen perilaku yang berhubungan dengan kejadian pneumonia adalah anggota keluarga merokok ( $p$ value: $0,033, \mathrm{OR}=4,041)$ dan kebiasaan membuka jendela ( $p$ value: $0,045, \mathrm{OR}=$ 2,455 ). Saran yang diberikan adalah mengurangi kebiasaan merokok di dalam rumah, meningkatkan pengetahuan mengenai rumah sehat dan pencegahan pneumonia serta rutin melakukan perbaikan lingkungan rumah dengan cara membersihkan rumah.
\end{abstract}

Kata Kunci : : Pneumonia, Rumah Sehat, Komponen Rumah, Komponen Perilaku

1)Alumni Prodi D4 Kesehatan Lingkungan Poltekkes Tanjungkarang

\section{PENDAHULUAN}

Dari tahun ke tahun, Pneumonia menduduki peringkat atas penyebab kematian bayi dan balita di Indonesia. Berdasarkan Survei Kematian Balita tahun 2005, sebagian besar disebabkan karena pneumonia 23,6\%. Selama ini digunakan estimasi bahwa insidens pneumonia pada kelompok umur Balita di Indonesia sekitar 10-20\%. (Kemenkes RI, 2012). Provinsi Lampung termasuk ke dalam provinsi dimana insiden pneumonia balita tertinggi $(>4 \%)$ pada tahun 2005 . Insidens pneumonia tersebar di seluruh provinsi di Indonesia, dimana hal tersebut dipengaruhi oleh status gizi, sosial ekonomi, sosial budaya, lingkungan, perilaku masyarakat, dan lain-lain (Kemenkes RI, 2010).

Data dari Dinas Kesehatan Provinsi Lampung, laporan pneumonia yang masuk ke Dinas Keschatan Provinsi Lampung sejak tahun 2011-2015 yaitu pada tahun 2011 sebanyak
11,121 kasus, kemudian pada tahun 2012 jumlah kasus menurun menjadi 7.931 kasus, lalu naik kembali pada tahun berikutnya sebanyak 14.106 kasus, kemudian pada tahun 2014 turun menjadi 11.163 kasus, dan tahun berikutnya menjadi 7.717 kasus (Dinkes Provinsi Lampung, 2015).

Lampung Tengah termasuk dalam 5 kabupaten tertinggi kasus pneumonia pada balita. Berdasarkan data profil dinas kesehatan Provinsi Lampung, lampung tengah berada di posisi ke empat kasus pneumonia tertinggi dibandingkan dengan 15 kabupaten lainnya di Provinsi Lampung dari tahun 2013-2015. Jumlah kasus pneumonia pada balita di Kabupaten Lampung Tengah pada tahun 2013 sebesar 1.399 kasus, kemudian meningkat pada tahun berikutnya yaitu sebesar 1.498 kasus dan tahun 2015 turun menjadi 1.007 kasus (Dinkes Provinsi Lampung, 2015). 
Jumlah kasus pneumonia pada balita yang dilaporkan puskesmas di Kabupaten Lampung Tengah dalam periode 2011-2016 cenderung naik turun. Kasus Pneumonia balita di Kabupaten Lampung Tengah tahun 2016 sebesar 769 kasus (6,67 per 1.000 balita), dimana mengalami penurunan dibandingkan tahun sebelumnya yaitu sebesar 1.007 kasus ( 8,48 per 1.000 balita). Kasus pneumonia pada kelompok umur $1-<5$ tahun lebih tinggi yaitu $63,07 \%$ dibandingkan dengan kelompok umur $<1$ tahun yaitu sebesar 36,9\% (Dinkes Kabupaten Lampung Tengah 2016).

Berdasarkan Profil Dinas Kesehatan Kabupaten Lampung Tengah Tahun 2014 2016, kasus pneumonia balita tertinggi berturutturut diantara 28 kecamatan di Kabupaten Lampung Tengah terdapat di Wilayah Kerja Puskesmas Seputih Agung yaitu sebanyak 265 kasus atau sebesar 57,19\% pada tahun 2014, 226 kasus atau sebesar 48,45\% pada tahun 2015 dan pada tahun berikutnya meningkat menjadi 338 kasus atau sebesar $73,61 \%$ (Dinkes Kabupaten Lampung Tengah, 2016).

Penyakit ISPA merupakan penyakit dengan jumlah kasus terbanyak diantara 10 besar penyakit lainnya berdasarkan data Puskesmas Simpang Agung. Dari tahun 2015-2016 penyakit ISPA menempati urutan teratas yaitu sebesar 9.046 kasus pada tahun 2015 dan mengalami penurunan menjadi 8.146 kasus. Sementara pada tahun 2017, penyakit gangguan pernafasan atas yaitu influenza dan nasopharingitis (common cold) menjadi urutan pertama sebesar 4.212 kasus. Berdasarkan catatan bulanan program ISPA Puskesmas Simpang Agung, jumlah kasus pneumonia pada balita di Wilayah Kerja Puskesmas Simpang Agung pada tahun 2017 sebesar 64 kasus. Desa tertinggi dengan kasus pneumonia terdapat pada Desa Sulusuban yaitu sebesar 10 kasus dibandingkan dengan 10 desa lainnya dan terendah terdapat di Desa Fajar Asri yaitu sebanyak 2 kasus (Puskesmas Simpang Agung, 2017).

\section{METODE}

Jenis penelitian yang digunakan adalah studi analitik, yaitu penelitian yang digunakan untuk mencoba menggali bagaimana dan mengapa suatu fenomena kesehatan terjadi dan melakukan analisis dinamika korelasi antara faktor risiko dan faktor efek (Notoatmodjo, 2012: 37) dengan rancangan penelitian kasus kontrol (case contrbl). Uji yang digunakan yaitu uji chi square dengan variabel bebas yaitu komponen rumah (ventilasi, langit-langit, dinding, lantai, jendela ruang keluarga, jendela kamar tidur, lubang asap dapur, dan kepadatan Hunian) serta perilaku (kebiasaan merokok anggota keluarga, membuka jendela dan penggunaan obat nyamuk bakar) dan variabel terikat yaitu kejadian pneumonia pada balita. Penelitian ini dilaksanakan di wilayah kerja Puskesmas Simpang Agung Kecamatan Seputih Agung Kabupaten Lampung Tengah pada bulan Juni sampai dengan Juli tahun 2018.

Populasi pada penelitian ini adalah seluruh balita yang tercatat sebagai penderita pneumonia di wilayah kerja Puskesmas Simpang Agung dan seluruh balita yang bukan sebagai penderita pneumonia di wilayah kerja Puskesmas Simpang Agung. Dalam menentukan besarnya sampel menggunakan rumus (Schlesselman,1982 dalam Basuki, 2000).

Tabel 1. Perhitungan Jumlah Sampel Minimal

\begin{tabular}{clcccl}
\hline No & \multicolumn{1}{c}{ Variabel } & P0 & OR & Sampel & \multicolumn{1}{c}{ Peneliti } \\
\hline 1 & Paparan Asap Rokok dalam Rumah & 0,33 & 4,00 & 30 & Mahalastri, 2014 \\
2 & Kepadatan Hunian & 0,533 & 4,38 & 30 & Mahalastri, 2014 \\
3 & Lubang Asap Dapur & 0,329 & 3,458 & 35 & Sari, 2017 \\
4 & Ventilasi & 0,36 & 3,451 & 50 & Sayiddah, 2017 \\
\hline
\end{tabular}

Dari hasil perhitungan sampel merujuk pada tabel 1, diperoleh 50 sampel kasus dan 50 kontrol. Sampel ditentukan berdasarkan dengan kriteria sebagi berikut:

1. Kriteria Inklusi Kasus

a. Anak yang berumur $12-59$ bulan (balita) b. Tercatat positif dalam buku register pneumonia di wilayah kerja Puskesmas Simpang Agung pada tahun 2018

c. Orang tua sebagai perwakilan dari balita penderita pneumonia bersedia menjadi responden dalam penelitian ini dan menandatangani informed consent. 
d. Tempat tinggal balita penderita pneumonia berada di wilayah kerja Puskesmas Simpang Agung

e. Dapat berkomunikasi dengan baik

2. Kriteria Eksklusi Kasus

a. Balita menderita penyakit pernafasan seperti common cold, TBC, influenza, batuk rejan (pertusis), dan lain-lain

b. Orang tua sebagai perwakilan dari balita penderita pneumonia tidak bersedia menjadi responden dalam penelitian ini.

c. Tempat tinggal atau rumah balita penderita pneumonia tidak berada di wilayah kerja Puskesmas Simpang Agung

\section{HASIL}

1. Hubungan Perilaku dengan Pneumonia

Dari tabel 2, diketahui bahwa komponen perilaku yang berhubungan dengan kejadian pneumonia pada balita di Wilayah Kerja Puskesmas Simpang Agung Kabupaten Lampung Tengah adalah kebiasaan anggota keluarga merokok, tempat merokok anggota keluarga dan kebiasaan membuka jendela. Dan variabel yang tidak memiliki hubungan adalah penggunaan obat nyamuk bakar.

Tabel 2. Hubungan Faktor Perilaku dengan Kejadian Pneumonia pada Balita

\begin{tabular}{|c|c|c|c|c|}
\hline No & Perilaku & p value & OR (CI:95\%) & Keterangan \\
\hline 1 & $\begin{array}{l}\text { Kebiasaan Anggota } \\
\text { Keluarga Merokok }\end{array}$ & 0,033 & $\begin{array}{c}4.041 \\
(1,215-13,433)\end{array}$ & Ada hubungan \\
\hline 2 & $\begin{array}{l}\text { Tempat Merokok Anggota } \\
\text { Keluarga }\end{array}$ & 0,042 & $\begin{array}{c}1.527 \\
(2,889-4,981)\end{array}$ & Ada hubungan \\
\hline 3 & $\begin{array}{l}\text { Kebiasaan Membuka } \\
\text { Jendela }\end{array}$ & 0,045 & $\begin{array}{c}2.455 \\
(1,097-5,494)\end{array}$ & Ada hubungan \\
\hline 4 & Penggunaan Obat Nyamuk & 0,679 & - & Tidak Ada hubungan \\
\hline
\end{tabular}

2. Hubungan Komponen Rumah dengan Pneumonia

Tabel 3 menggambarkan hubungan komponen rumah dengan kejadian pneumonia pada balita di Wilayah Kerja Puskesmas Simpang Agung Kabupaten Lampung Tengah adalah ventilasi, langit-langit dan lantai.

Tabel 3. Hubungan Komponen Rumah dengan Kejadian Pneumonia pada Balita

\begin{tabular}{|c|c|c|c|}
\hline Komponen Rumah & p value & OR (CI:95\%) & Keterangan \\
\hline Ventilasi & 0.033 & $\begin{array}{c}4.041 \\
(1,215-13,433)\end{array}$ & Ada hubungan \\
\hline Langit-Langit & 0,017 & $\begin{array}{c}6.769 \\
(1,416-32,367)\end{array}$ & Ada hubungan \\
\hline Dinding & 1.000 & - & Tidak ada hubungan \\
\hline Lantai & 0,038 & $\begin{array}{c}2.627 \\
(1,133-6,091)\end{array}$ & Ada hubungan \\
\hline Jendela Ruang Keluarga & - & - & Tidak ada hubungan \\
\hline Jendela Kamar Tidur & - & - & Tidak ada hubungan \\
\hline Lubang Asap Dapur & 0,739 & - & Tidak ada hubungan \\
\hline Kepadatan Hunian & 0,523 & - & Tidak ada hubungan \\
\hline
\end{tabular}

\section{PEMBAHASAN}

\section{Hubungan Perilaku dengan Pneumonia}

Berdasarkan tabel 2, dapat diketahui bahwa komponen perilaku yang berhubungan dengan kejadian pneumonia pada balita di Wilayah Kerja Puskesmas Simpang Agung Kabupaten Lampung Tengah adalah kebiasaan anggota keluarga merokok, tempat merokok anggota keluarga dan kebiasaan membuka jendela. Dan variabel yang tidak memiliki hubungan adalah penggunaan obat nyamuk bakar.

Merokok diketahui dapat mengganggu efektivitas sebagian mekanisme pertahanan respirasi. Produk asap rokok merangsang 
produksi mucus dan menurunkan pergerakan silia. Dengan demikian, terjadi akumulasi mucus yang kental dan terperangkapnya partikel atau mikroorganisme di jalan napas, yang dapat menurunkan pergerakan udara dan meningkatkan risiko pertumbuhan mikroorganisme. Batuk-batuk yang terjadi pada para perokok (smoker's cough) adalah usaha untuk mengelurakan mucus kental yang sulit didorong keluar dari saluran napas. Infeksi saluran napas bawah lebih sering terjadi pada perokok dan mereka yang perokok pasif, terutama bayi dan anak (Corwin, 2009).

Paparan asap rokok adalah suatu penyebab utama penyakit pneumonia dan peningkatan risiko infeksi paru-paru pada orang dewasa dan anak-anak (Aditama, 2013). Asap rokok mengandung sekitar 4.000 jenis senyawa kimia beracun yang berbahaya untuk tubuh dimana 43 di antaranya bersifat karsinogen (penyebab kanker). Pengaruh asap rokok pada perokok pasif tiga kali lebih buruk dibandingkan dengan debu batu bara.

Hubungan antara kebiasaan keluarga yang merokok dengan kejadian pneumonia pada balita tersebut dapat disebabkan karena kebiasaan orang tua merokok dalam rumah merupakan faktor yang terkait dengan terjadinya penyakit pernapasan pada anak dan tingginya kadar partikulat dalam rumah. Rokok terhadap penyakit pernapasan ternyata menambah berat gejala eksaserbasi asma dan penyakit-penyakit saluran pernapasan lain. Balita yang terpapar asap rokok di rumah, berisiko terkena infeksi pernafasan empat kali dibandingkan dengan bayi yang tidak terpajan (Sari, 2017).

Disampaikan pula oleh Mahalastri (2014) bahwa adanya perokok aktif didalam rumah dapat meningkatkan pajanan asap rokok kepada anggota keluarganya. Selain itu rokok juga dapat menimbulkan gangguan kesehatan bukan hanya bagi perokok aktif, namun juga menimbulkan gangguan kesehatan bagi perokok pasif. Karena perokok pasif dikatakan tidak memiliki kekebalan yang cukup terhadap bahan berbahaya yang dihasilkan oleh rokok.

Berdasarkan hasil wawancara, anggota keluarga yang merokok biasa dilakukan oleh orang tua (ayah) atau kakek balita. Anggota keluarga yang merokok lebih sering merokok di dalam rumah sehingga memungkinkan balita terpapar asap rokok. Paparan asap rokok yang terjadi secara terus menerus inilah yang memungkinkan menjadi salah satu faktor penyebab pneumonia pada balita.

Kclompok kasus yang tidak memiliki anggota keluarga yang merokok akan tetapi menjadi responden kasus dapat terjadi dikarenakan faktor lain diluar variabel merokok sehingga menjadi salah satu faktor risiko pneumonia pada kelompok kasus. Hal tersebut seperti komponen rumah yang tidak memenuhi syarat schingga mempengaruhi suhu, kelembaban dan lain-lain yang dapat menjadi pendukung perkembangbiakan bakter atau virus yang menjadi salah satu penyebab pneumonia.

Kemudian untuk kelompok kontrol yang memiliki anggota keluarga yang merokok akan tetapi tidak memiliki anak balita dengan pneumonia dapat terjadi karena kebiasaan anggota keluarga merokok yang tidak dilakukan di dalam rumah serta didukung oleh komponen rumah serta perilaku yang memenuhi syarat. Sehingga dapat menurunkan resiko terjadinya pneumonia walaupun memiliki anggota keluarga yang merokok.

Diharapkan kepada anggota keluarga untuk mengurangi kebiasaan merokok di dalam rumah terutama ketika berada di dekat balita maupun anggota keluarga lain. Karena rokok tidak hanya menyebabkan gangguan kesehatan terhadap orang yang merokok akan tetapi berdampak pula pada orang yang terkena paparan asap rokok (perokok pasif). Salah satu Perilaku Hidup Bersih dan Sehat (PHBS) tatanan rumah tangga adalah tidak merokok di dalam rumah, sehingga diperlukan kesadaran anggota keluarga dalam menerapkan PHBS ditatanan rumah tangga tersebut.

Kebiasaan membuka jendela akan memudahkan cahaya dan sirkulasi udara masuk ke rumah. Cahaya dan sirkulasi udara akan mempengaruhi suhu dan kelembaban ruangan. Suhu dan kelembaban ini sangat erat kaitannya dengan pertumbuhan dan perkembangbiakan faktor etiologi pneumonia yang berupa bakteri, virus dan jamur (Sari, 2017).

Hasil penelitian ini berbeda dengan penelitian yang dilakukan sebelumnya oleh Sari (2017), yang menyatakan bahwa tidak ada hubungan yang bermakna antara membuka jendela dengan pneumonia, dimana $p$-value yang di dapatkan sebesar 1,000 dengan $O R$ 0,917 .

Responden yang membuka jendela setiap hari pada kelompok kasus akan tetapi masih memiliki anak balita yang terkena pneumonia diakibatkan karena variabel lain selain variabel 
membuka jendela. Salah satunya kebiasaan merokok anggota keluarga yang masih dilakukan di sckitar balita atau faktor lain seperti komponen rumah yang belum memenuhi syarat dan faktor lingkungan di luar rumah seperti kondisi debu. Faktor tersebut dapat menjadi salah satu faktor penyebab pneumonia walau responden telah membuka jendela setiap hari. Responden dengan kebiasaan yang kadang-kadang membuka jendela akan tetapi tidak terkena pneumonia (kelompok kontrol) dapat terjadi karena memiliki lingkungan rumah yang telah memenuhi syarat, baik ventilasi, lantai dan lain sebagainya. Sehingga hal tersebut dapat mengurangi resiko terjadinya pneumonia pada balita.

Untuk responden dengan komponen jendela rumah yang tidak dapat dibuka atau ditutup sebaiknya dilakukan perbaikan komponen jendela dengan pembuatan 1 atau 2 jendela yang dapat dibuka dan ditutup, atau memperbaiki ventilasi rumah sebagai sarana pengganti sirkulasi udara di dalam rumah serta diperlukan kesadaran mengubah perilaku atau kebiasaan keluarga dalam membuka jendela. Kebiasaan membuka jendela dilakukan secara rutin guna memperbaiki kondisi dalam rumah yang akan berpengaruh terhadap pencahayaan serta sirkulasi udara di dalam rumah.

Penggunaan pestisida di dalam rumah merupakan salah satu penyebab polusi udara di dalam rumah yang berdampak pada kesehatan penghuninya (Mahalastri, 2014). Asap yang dihasilkan oleh obat nyamuk bakar akan menyebabkan rangsangan pada saluran pernapasan pada balita, sehingga balita menjadi rentan terinfeksi oleh bakteri atau virus yang menyebabkan terjadinya pneumonia (Amin, 2015).

Hasil penelitian ini memiliki perbedaan dengan penelitian sebelumnya yang dilakukan oleh Annah, dkk (2012), dimana pada penelitiannya di dapatkan hubungan yang bermakna antara penggunaan obat nyamuk bakar $(\mathrm{OR}=6,34 ; 95 \%$ CI 2,912 - 13.800). Berdasarkan hal tersebut, dapat disimpulkan bahwa keluarga yang menggunakan obat nyamuk memiliki risiko 6,34 kali lebih besar untuk menderita pneumonia dibandingkan dengan yang tidak menggunakan obat nyamuk.

Disampaikan pula oleh Amin (2015) bahwa obat nyamuk bakar mengandung insektisida yang disebut d-aletrin $0,25 \%$. Selain itu, yang dihasilkan dari pembakaran yaitu $\mathrm{CO}$ dan $\mathrm{CO}_{2}$ serta partikulat-partikulat yang bersifat iritan terhadap saluran pernafasan. Jadi penggunaan obat anti nyamuk bakar mempunyai efek yang merugikan kesehatan, termasuk dapat bersifat iritan terhadap saluran pernafasan, yang dapat menimbulkan dampak berlanjut yaitu mudah terjadi infeksi saluran pernafasan.

Penggunaan obat nyamuk memang menjadi salah satu cara untuk mencegah gigitan nnyamuk akan tetapi tentunya dapat memberikan efek negatif terutama dengan menggunakan obat nyamuk bakar, sebaiknya responden mengurangi penggunaan obat nyamuk dan lebih memilih dengan menggunakan kelambu, hal tersebut lebih menghemat biaya serta dapat pula menjadi salah, satu cara pencegahan gigitan nyamuk yang efektif.

\section{Hubungan Komponen Rumah dengan Pneumonia}

Pertukaran udara yang tidak memenuhi syarat dapat menyebabkan pertumbuhan mikroorganisme yang mengakibatkan gangguan terhadap kesehatan manusia. Berdasarkan Kepmenkes RI No 829 Tahun 1999, luas penghawaan atau ventilasi alamiah yang permanen minimal $10 \%$ dari luas lantai.

Hasil observasi menunjukan bahwa masih terdapat rumah balita yang memiliki ventilasi tidak memenuhi syarat, yaitu dikarenakan kurangnya luas ventilasi yang menjadi aliran keluar masuknya udara serta bebcrapa responden yang menutup ventilasi dengan menggunakan bahan tertentu yang menyebabkan terhambatnya aliran udara di dalam rumah.

Penelitian ini memiliki hubungan dengan peneltian sebelumnya. Berdasarkan penelitian Mahalastri (2014), menyatakan bahwa luas ventilasi ruangan bermakna atau mempunyai hubungan dengan kejadian pneumonia pada balita. Selain itu dapat diketahui bahwa rumah responden yang tergolong memiliki ventilasi ruangan yang kurang dari syarat minimal berisiko 4,03 kali lebih besar dibandingkan dengan balita yang tinggal di rumah dengan luas ventilasi ruangan yang memenuhi standar.

Kondisi ventilasi sering berkaitan dengan kelembaban. Kelembaban tinggi dapat disebabkan oleh uap air dari keringat manusia maupun pernapasan. Kelembaban dalam ruang tertutup dimana terdapat banyak manusia di dalamnya lebih tinggi kelembabannya dibanding diluar ruangan. Semakin lama balita tinggal pada rumah yang memiliki ventilasi tiak 
memenuhi syarat, maka semakin tinggi kemungkinan balita menderita pneumonia (Sari, 2017).

Tidak tersedianya ventilasi yang baik pada suatu ruangan makin membahayakan kesehatan, jika kebetulan dalam ruangan tersebut terjadi pula pencemaran oleh bakteri ataupun oleh berbagai zat kimia (organik atau anorganik). Keberadaan bakteri di udara dikarenakan adanya debu, uap air yang mengandung kuman. Setiap gram debu jalanan mengandung kira-kira 50 juta bakteri, debu yang teredapat di dalam ruangan mengandung sekitar 5 juta bakteri per gram. Bakteri yang sering melayang di udara adalah bakteri yang hidup pada saluran pernapasan manusia yang dikeluarkan melalui bersin, batuk, bernapas ataupun saat berbicara. Pneumonia dan tuberculosis sangat berpotensi menular di dalam rumah dengan kondisi yang tidak memenuhi syarat kesehatan Padmonobo, dkk, 2011).

Langit-langit rumah berada dibawah kerangka atap atau kuda-kuda, yang bertujuan untuk menutup seluruh konstruksi agar tidak terlihat \& rapi, menahan debu, kotoran lain dan air hujan jatuh melalui celah atap dan membuat ruangan antara yaitu sebagai penyekat sehingga panas tidak mudah menjalar ke dalam ruangan

Hasil observasi pada rumah responden, memang masih banyak rumah dengan tidak memiliki langit-langit rumah. Dan juga terdapat rumah yang sudah memiliki langit-langit rumah, akan tetapi dalam keadaan kotor. Beradasarkan hal tersebut, penilaian mengenai langit-langit rumah menjadi tidak memenuhi syarat, dikarenakan kriteria langit-langit rumah adalah memiliki langit-langit rumah, dalam keadaan bersih dan mudah dibersihkan.

Oleh karena itu, diperlukan pembersihan secara rutin serta perbaikan komponen rumah terutama langit-langit rumah guna mengurangi resiko penyakit pneumonia serta meningkatkan pengetahuan masyarakat mengenai rumah sehat, sehingga dapat menambah wawasan dan meningkatkan kepemilikan rumah sehat di wilayah kerja Puskesmas Simpang Agung.

Dinding rumah yang tidak memenuhi syarat menyebabkan kelembaban dalam ruangan menjadi tidak normal. Kelembaban tidak normal ini akan menjadi prakondisi pertumbuhan kuman maupun bakteri pathogen yang dapat menimbulkan penyakit bagi penghuninya (Padmonobo, dkk, 2011).

Dimana berdasarkan Keputusan Menteri Kesehatan Republik Indonesia Nomor
829/Menkes/SK/VII/1999 tentang persyaratan rumah tinggal menyebutkan bahwa jenis dinding tidak tembus pandang, terbuat dari bahan yang tahan terhadap cuaca, rata dan dilengkapi dengan ventilasi untuk sirkulasi udara. Dinding rumah yang baik menggunakan tembok, rumah yang berdinding tidak rapat seperti papan, kayu dan bambu dapat menyebabkan penyakit pernapasan yang berkelanjutan seperti ISPA dan pneumonia, karena angin malam yang langsung masuk ke dalam rumah.

Begitu pula terhadap penelitian Pangandaheng (2014) bahwa hasil uji statistik diperoleh kesimpulan antara kondisi dinding rumah dengan kejadian pneumonia tidak memiliki hubungan yang bermakna dengan kejadian pneumonia nilai $p=0,45(p>0,05)$. Selain itu, kondisi dinding rumah tidak langsung dengan kejadian pneumonia. Hal ini dipengaruhi oleh kelembaban dan pencahayaan di dalam ruangan yang dapat menjadi tempat perkembangan bakteri sehingga dapat menimbulkan penyakit pneumonia.

Hasil observasi didapatkan bahwa masih terdapat rumah yang belum memenuhi syarat, dikarenakan kondisi rumah masih semi permanen. Hal tersebut terdapat pada kelompok kontrol. Walaupun demikian, pada responden ini tidak terdapat balita dengan pneumonia, hal tersebut dapat terjadi karena didukung oleh perilaku anggota keluarga yang tidak merokok di dalam rumah atau didukung hal lain seperti komponen rumah lainnya yang telah memenuhi syarat atau tidak terdapat faktor di luar lingkungan rumah yang menjadi salah satu faktor risiko pneumonia.

Diperlukannya perbaikan komponen rumah guna mencegah risiko pneumonia pada balita serta meningkatkan pengetahuan masyarakat mengenai rumah sehat sehingga masyarakat mampu memiliki rumah yang sehat serta mengurangi kejadian pneumonia di wilayah kerja UPT Puskesmas Simpang Agung. Hal tersebut tidaklah mudah dikarenakan hal ini terkait dengan tingkat ekonomi serta sosial masyarakat, sehingga diperlukan kerja sama antara pihak terkait guna melakukan perbaikan.

Lantai yang berdebu merupakan salah satu bentuk polusi udara dalam rumah. Debu dalam udara bila terhirup akan menempel pada saluran napas bagian bawah. Akumulasi tersebut akan menyebabkan elastisitas paru menurun, sehingga menyebabkan balita sulit bernapas. Hal ini juga didukung oleh teori yang 
menyatakan bahwa lantai yang baik harus kedap air, tidak lembab, bahan lantai mudah dibersihkan dan dalam keadaan kering dan tidak menghasilkan debu (Pramudiyani; Galuh, 2011).

$\mathrm{Hal}$ ini sejalan dengan peneltian sebelumnya olch Padmonobo, dkk (2011) bahwa hasil analisis statistik menyatakan nilai $p=0,008$ dan $\mathrm{OR}=2,635$ dengan $\mathrm{CI} 95 \%=$ $1,341<\mathrm{OR}<5,178$. Nilai $\mathrm{p}<0,05$ dapat diinterpretasikan secara statistik bahwa ada hubungan yang bermakna yang signifikan antara jenis lantai rumah dengan kejadian pneumonia pada balita, sehingga jenis lantai rumah tidak permanen menjadi faktor resiko kejadian pneumonia pada balita. Dari nilai odds ratio dapat diketahui bahwa balita yang tinggal di rumah dengan lantai tidak permanen mempunyai resiko menderita pneumonia 2,635 kali lebih besar dibanding balita yang tinggal di rumah dengan lantai permanen.

Hubungan antara jenis lantai dengan kejadian pneumonia pada balita yang bersifat tidak langsung, lantai yang kedap air (jenis lantai tanah) dapat mempengaruhi kelembaban di dalam rumah dan kelembaban dapat mempengaruhi berkembangbiaknya kuman penyebab pneumonia. Hubungan yang bersifat langsung dapat terjadi karena lantai rumah yang terbuat dari tanah akan menyebabkan kondisi dalam rumah menjadi berdebu. Keadaan berdebu ini sebagai salah satu bentuk terjadinya polusi udara dalam rumah (indoor air pollution). Debu dalam udara apabila terhirup akan menempel pada saluran napas bagian bawah. Akumulasi penempelan debu tersebut akan menyebabkan elastisitas paru menurun sehingga menyebabkan balita sulit bernapas ataupun sesak napas (Padmonobo, dkk, 2011).

Diperlukannya pembersihan secara rutin serta perbaikan komponen rumah yaitu lantai rumah guna mencegah risiko pneumonia yang diakibatkan komponen lantai rumah yang tidak memenuhi syarat. Pengetahuan mengenai rumah sehat juga perlu diberikan kepada masyarakat guna meningkatkan kesadaran dalam memiliki lingkungan rumah yang sehat. Serta untuk peneliti lain dapat melakukan penelitian lebih lanjut mengenai pengaruh polusi udara di luar rumah yang mungkin dapat menjadi salah satu resiko terjadinya pneumonia pada balita.

Jendela pada rumah harus dapat dibuka pada siang hari yang bertujuan agar cahaya matahari dapat masuk, dan sirkulasi udara berjalan lancar. Luas jendela $10-20 \%$ luas lantai. Pada rumah sekurang-kurangnya memiliki 1 atau lebih jendela yang dapat berhubungan langsung dengan udara bebas.

Jendela kamar tidur merupakan bagian dinding yang dapat dibuka agar udara segar dan sinar matahari dapat masuk ke ruang tidur sehingga dapat membunuh organisme di dalamnya. Jendela kamar tidur dikatakạn tidak berfungsi apabila jendela tersebut selalu ditutup pada siang hari. Suatu kamar tidur yang memiliki jendela tetapi tidak pernah dibuka akan membuat kamar tidur menjadi pengap dan lembab (Alfaqinisa, 2015).

Pembakaran yang terjadi di dapur rumah merupakan aktivitas manusia yang menjadi sumber pengotoran atau pencemaran udara. Pengaruh terhadap kesehatan akan tampak apabila kadar zat pengotor meningkat sedemikian rupa sehingga timbul penyakit. Pengaruh zat kimia ini pertama-tama akan ditemukan pada sistem pernafasan dan kulit serta selaput lendir, selanjutnya apabila zat pencemar dapat memasuki peredaran darah, maka efek sistemik tak dapat dihindari (Juli Soemirat dalam Sari, 2017).

Fungsi lubang asap dapur yaitu menurunkan tingkat polusi dalam rumah. Polusi udara di dalam ruangan dari bahan bakar biomassa telah terbukti meningkatkan risiko pneumonia pada anak sekitar $80 \%$. Dapur juga termasuk ruangan dalam rumah yang harus memiliki ventilasi agar asap sisa pembakaran saat proses memasak dapat berganti dengan udara segar. Lubang asap dapur dapat menurunkan aerosol dan polusi udara dalam dapur tersebut (Hidayat; Suhartono; Dharminto, 2016)

Berdasarkan Kepmenkes RI Nomor $829 / 1999$, dapur yang sehat harus memiliki lubang asap dapur. Di perkotaan, dapur sudah dilengkapi dengan penghisap asap. Lubang asap dapur yang tidak memenuhi persyaratan menyebabkan: gangguan terhadap pernapasan dan mungkin dapat merusak alat-alat pernapasan, lingkungan rumah menjadi kotor dan gangguan terhadap penglihatan/ mata menjadi pedih.

Responden yang telah memiliki lubang asap dapur akan tetapi masuk dalam kelompok kasus atau memiliki balita dengan pneumonia dapat diakibatkan karena faktor lain selain kepemilikan lubang asap dapur. Polusi udara di dalam rumah yang terjadi akibat asap rokok, faktor lingkungan di luar rumah seperti intensitas debu yang merupakan salah satu 
polusi udara dari luar rumah dapat pula menjadi salah satu penyebab pneumonia pada balita. Komponen rumah lainnya yang tidak memenuhi syarat yang berdampak pada suhu dan kelembaban dalam rumah juga menjadi salah satu penyebab hal tersebut. Sehingga walaupun responden telah memiliki lubang asap dapur, namun risiko pneumonia dapat pula diakibatkan oleh faktor lainnya.

Sedangkan untuk responden yang tidak memiliki lubang asap dapur akan tetapi tidak memiliki balita dengan pneumonia dapat terjadi karena kurangnya intensitas polusi udara lainnya dari dalam maupun luar rumah seperti asap rokok dan debu.

Perbaikan komponen rumah terutama lubang asap dapur sangat diperlukan. Karena hal tersebut terkait dengan sirkulasi udara untuk mengeluarkan polusi dari asap pembakaran di dapur. Peningkatan pengetahuan masyarakat mengenai rumah sehat juga sangat diperlukan, karena akan terkait dengan meningkatkan jumlah rumah sehat serta menurunkan kasus pneumonia di wilayah kerja Puskesmas Simpang Agung.

Pemanfaatan atau penggunaan rumah perlu sekali diperhatikan. Banyak rumah secara teknis memenuhi syarat kesehatan, tetapi apabila penggunaannya tidak sesuai dengan peruntukannya, maka dapat terjadi gangguan kesehatan. Misalnya rumah yang dibangun untuk dihuni oleh empat orang tidak jarang dihuni oleh lebih dari semestinya (Juli Soemirat dalam Sari, 2017).

Tingkat kepadatan hunian yang tidak memenuhi syarat disebabkan karena luas rumah yang tidak sebanding dengan jumlah keluarga yang menempati rumah. Luas rumah yang sempit dengan jumlah anggota keluarga yang banyak menyebabkan rasio penghuni dengan luas rumah tidak seimbang (Amin, 2015). Kepadatan hunian ini memungkinkan bakteri maupun virus dapat menyebabkan mudahnya penularan bakteri maupun virus melalui pernapasan diantara penghuni rumah yang satu dengan yang lainnya.

Penelitian ini sejalan dengan penelitian sebelumnya oleh Hidayat, dikk (2016), dimana hasil analisis statistic mendapatkan $p$ value sebesar 0,478 dan Odds Ratio $(\mathrm{OR})=2,188$; $95 \% \mathrm{Cl}=0,505-9,480$ sehingga disimpulkan bahwa tidak ada hubungan bermakna antara kondisi kepadatan hunian rumah dengan kejadian pneumonia pada balita dan variabel kepadatan hunian rumah cenderung menjadi faktor risiko.

Kepadatan hunian terkait dengan kemudahan penularan penyakit. Kelompok kontrol yang belum memenuhi syarat dalam hal kepadatan hunian dan tidak memiliki balita dengan pneumonia dapat terjadi karena adanya resistensi di dalam tubuh anggota keluarga serta sumber yang tidak berasal dari padatnya hunian menjadi salah satu hal yang mengakibatkan hal tersebut terjadi serta didukung dengan komponen rumah yang telah memenuhi syarat seperti ventilasi, karena walaupun hunian padat akan tetapi didukung oleh sirkulasi udara yang lancar akan dapat mengrangi resiko pneumonia pada balita. Hal tersebut juga berkaitan dengan suhu dan kelembaban di dalam rumah.

Sosialisasi mengenai rumah sehat dan pencegahan pneumonia dibutuhkan bagi masyarakat guna meningkatkan pengetahuan serta meningkatkan derajat kesehatan masyarakat, meningkatkan kepemilikan rumah sehat dan menurunkan kejadian pneumonia pada balita di wilayah kerja Puskesmas Simpang Agung.

\section{KESIMPULAN}

1. Kondisi rumah berdasarkan penilaian komponen rumah sehat sebesar $53(53 \%)$ rumah dan yang tidak sehat sebanyak 47 $(47 \%)$ rumah, sedangkan untuk perilaku yang sehat sebanyak $44(44 \%)$ rumah dan perilaku yang tidak sehat sebanyak 56 (56\%) rumah

2. Komponen rumah yang berhubungan dengan kejadian pneumonia pada balita di Wilayah Kerja Puskesmas Simpang Agung Kabupaten Lampung Tengah adalah ventilasi ( $p$ value: 0,03 ), langit-langit $(p$ value $: 0,017)$ dan lantai $(p$ value $: 0,038)$

3. Komponen perilaku yang berhubungan dengan kejadian pneumonia pada balita di Wilayah Kerja Puskesmas Simpang Agung Kabupaten Lampung Tengah adalah perilaku merokok anggota keluarga ( $p$ value : 0,033) dan kebiasaan membuka jendela ( $p$ value 0,045$)$.

\section{DAFTAR PUSTAKA}

Kementerian Kesehatan Republik Indonesia 2012. Modul Tatalaksana Standar Pneumonia, Jakarta.

Kementerian Kesehatan Republik Indonesia, 2010. Buletin Jendela Epidemiologi: 
Pneumonia Balita. Kementerian Kesehatan Republik Indonesia, Jakarta

Dinas Kesehatan Provinsi Lampung, 2015. Profil Dinas Kesehatan Provinsi Lampung, Lampung

Dinas Kesehatan Kabupaten Lampung Tengah, 2016, Profil Dinas Kesehatan Kabupaten Lampung Tengah, Lampung Tengah

Puskesmas Simpang Agung, 2017. Catatan Bulanan Program ISPA Kabupaten Lampung Tengah Puskesmas Simpang Agung dan data 10 Besar Penyakit, Lampung Tengah

Notoatmodjo, Soekidjo., 2012. Metodologi Penelitian Kesehatan, Rineka Cipta, Jakarta, 243 Halaman

Basuki, Bastaman, 2000. Aplikasi Metode Kasus-Kontrol, Bagian Ilmu Kedokteran Komunitas Fakultas Kedokteran Universitas Indonesia, Jakarta, 188 halaman

Corwin, Elizabeth J, 2009. Buku Saku Patofisiologi, EGC, Jakarta, 842 Halaman.

Aditama, T.Y, 2013. Generasi Muda Sehat, Generasi Tanpa Rokok, Departemen Keschatan

Sari, Andyka Mertika, 2017. Faktor-Faktor Yang Berhubungan Dengan Kejadian Pneumonia Pada Balita Di Wilayah Kerja Puskesmas Yosomulyo Kota Metro Tahun 2017, Skripsi Diploma, Jurusan Kesehatan Lingkungan, Polteknik Kesehatan Tanjung Karang, Lampung.

Mahalastri, Ni Nyoman Ayu, 2014. Hubungan Antara Pencemaran Udara Dalam Ruang Dengan Kejadian Pneumonia Balita, Jurnal Berkala Epidemiologi, Fakultas Kesehatan Masyarakat, Universitas Airlangga, Surabaya

Amin, Zulfa Kamalia, 2015. Faktor Risiko yang Berhubungan dengan Kejadian Pneumonia Berulang, Skripsi Jurusan Ilmu Kesehatan Masyarakat Universitas Negeri Semarang, Semarang

Annah, Itma; Nawi, Rasdi; Ansar, Jumriani, 2012. Faktor Risiko Kejadian Pneumonia Anak Umur 6-59 Bulan di RSUD
Salewangan Maros Tahun 2012, Fakultas Kesehatan Masyarakat Universtas Hasanudin, Makassar

Menteri Kesehatan RI,_ 1999. Keputusan Menteri Kesehatan Republik Indonesia Nomor: $\quad$ 829/MENKES/SK/VII/1999 Tentang Persyaratan Kesehatan Perumahan, Menteri Kesehatan RI, Jakarta

Padmonobo, Heru, Setiani, Onny, Joko, Tri, 2011. Hubungan Faktor-Faktor Lingkungan Fisik Rumah dengan Kejadian Pneumonia pada Balita di Wilayah Kerja Puskesmas Jatibarang Kabupaten Brebes. Jurnal Kesehatan Indonesia. Brebes

Pangandaheng, Febbryani, Sondakh, Ricky C., Bernadus, Janno., 2014. Hubungan Antara Faktor-Faktor Lingkungan Fisik Rumah Dengan Kejadian Pneumonia Pada Balita Di Wilayah Kerja Puskesmas Tobelo Kabupaten Halmahera Utara. Fakultas Kesehatan Masyarakat Universitas Sam Ratulangi Manado dan Fakultas Kedokteran Universitas Sam Ratulangi Manado. Manado.

Pramudiyani, Novita Aris., Galuh, Nita Prameswari., 2011. Hubungan Antara Sanitasi Rumah Dan Perilaku Dengan Kejadian Pneumonia Balita, Jurnal Kesehatan Masyarakat, Fakultas IImu Keolahragaan, Universitas Negeri Semarang, Semarang.

Alfaqinisa, Rara, 2015. Hubungan Antara Tingkat Pengetahuann Sikap dan Perilaku Orang Tua Tentang Pneumonia dengan Tingkat Kekambuhan Pneumonia Pada Balita di Wilayah Kerja Puskesmas Ngesrep Kota Semarang Tahun 2015, Skripsi Ilmu Kesehatan Masyarakat Fakultas Ilmu Keolahragaan Universitas Negeri Semarang, Semarang.

Hidayat, Corry Wahyuni; Suhartono; Dharmito, 2016, Hubungan Kondisi Lingkungan Fisik Rumah dengan Kejadian Pneumonia pada Balita di Wilayah Kerja Puskesmas Jatibarang Kabupaten Indramayu, Bagian Kesehatan Lingkungan Fakultas Kesehatan Masyarakat Universitas Diponego. 